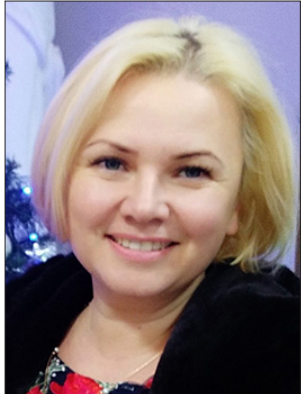

УДК (504.05+504.06):622.692.4

\section{STUDY OF THE LEVEL OF ENVIRONMENTAL SAFETY OF OPERATION OF OIL PIPELINES}

\section{ДОСЛІДЖЕННЯ РІВНЯ ЕКОЛОГІЧНОЇ БЕЗПЕКИ ЕКСПЛУАТАЦІЇ НАФТОПРОВОДІВ}

\section{DOI https:// doi.org/10.15589/smi2020.1(13).12}

Olena V. Stepova

Степова Олена Валеріївна, докт. техн. наук, доц. alenastepovaja@gmail.com ORCID: 0000-0002-6346-5484

Olena V. Stepova, Степова Олена Валеріївна

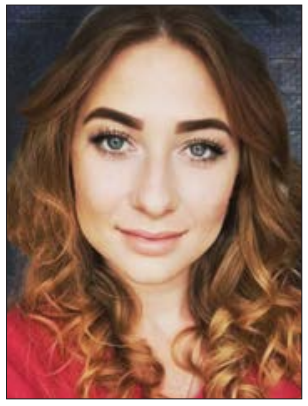

Anna S. Homenko, Хоменко Анна C.

\section{Anna S. Homenko}

Хоменко Анна С., магістр anna.khomenko1204@gmail.com

ORCID: 0000-0003-3046-6867

\section{National University "Yuri Kondratyuk Poltava Polytechnic”, Poltava}

Наџіональний університет «Полтавська політехніка імені Юрія Кондратюка», м. Полтава

Abstract. The article The article analyzes the indicators that assess the degree of environmental risk of oil pipelines, for which it is proposed to use the parameter of the flow of failures as an indicator that assesses the man-made level of safe operation of oil pipelines. It is expedient to consider in connection the technogenic and ecological risks of operation of oil pipelines with forecasting of ecological consequences in case of emergency. Reliability is an indicator of the reliability of renewable facilities, which include oil pipelines. Failure is assessed by the probability of trouble-free operation, the parameter of the flow of accidents and the period of time of accident-free operation. The advantage of the development is the ability to identify dangerous areas of oil pipelines, timely planning of repairs and prevention of accidents on oil pipelines. The probability of ecological threat due to corrosion processes on steel oil pipelines is calculated and its value is determined, which is one accident in 10 months.

Purpose. Perform calculations of probabilities of emergencies due to depressurization of steel pipelines, taking into account corrosion processes.

Method. The methodology is offered and the methods of carrying out researches which provided application of both theoretical and experimental methods, in particular methods of mathematical modeling, the theory of reliability are proved.

Results. According to the results of calculations, the most dangerous in terms of failure rate are oil pipelines: Mozyr-Brody I, II turn; Brody- State border I, II turn; withdrawal to Hungary km 0-21.4; Odesa-Brody.

Scientific novelty. It is established that the probability of ecological threat to the environment due to corrosion processes with depressurization of steel oil pipelines of Ukraine is 1,2 during the year. Practical importance. The results of this scientific work in combination with other studies will identify potential environmental threats from corrosion of pipelines and equipment in the use or disposal of petroleum waters, which will develop measures to prevent adverse effects during depressurization of pipelines.

Key words: steel pipeline, technogenic and ecological safety, reliability, failure, failure flow parameter.

Анотація. У статті проаналізовано показники, які оцінюють ступінь екологічного ризику нафтопроводів, для чого пропонується використовувати параметр потоку відмов як індикатор, що оцінює техногенний рівень безпечної експлуатації нафтопроводів. Доцільно розглядати у взаємозв'язку техногенно-екологічні ризики експлуатації нафтопроводів 3 прогнозуванням екологічних наслідків в разі виникнення аварійної ситуації. Показником надійності відновлюваних об’єктів, до яких відносять і нафтопроводи є безвідмовність. Безвідмовність оцінюється імовірністю безаварійної роботи, параметром потоку аварійних подій та проміжком часу безаварійної роботи. Перевагою розробки є можливість виявлення небезпечних ділянок нафтопроводів, своєчасне планування ремонтних робіт та запобігання виникненню аварійних ситуацій на нафтопроводах. Розраховано ймовірність виникнення екологічної загрози внаслідок прояву корозійних процесів на сталевих нафтопроводах і визначено іiі значення, яке складає одну аварію за 10 місяців.

Мета. Виконати розрахунки ймовірностей виникнення надзвичайних ситуацій внаслідок розгерметизації сталевих нафтопроводів з урахуванням корозійних процесів. 
Методика. Запропоновано методологію та обгрунтовано методики проведення досліджень, які передбачали застосування як теоретичних так і експериментальних методів, зокрема методи математичного моделювання, теорії надійності.

Результати. За результатими розрахунків виявлено, що найбільш небезпечними за показником потоку відмов є нафтопроводи: Мозир-Броди I, II черга; Броди-Держкородон I, II черга; відвід на Угорщину км 0-21,4; Одеса-Броди.

Наукова новизна. Встановлено, що ймовірність виникнення екологічної загрози довкіллю внаслідок корозійних процесів з розгерметизацією сталевих нафтопроводів України становить 1,2 протягом року.

Практична значимість. Результати даної наукової роботи в комплексі з іншими дослідженнями дадуть змогу визначити потенційні екологічні загрози від корозії трубопроводів, що дасть можливість розробити заходи по запобіганню виникнення шкідливих впливів при розгерметизації нафтопроводів.

Ключові слова: сталевий нафтопровід; техногенно-екологічна безпека; надійність; відмова; параметр потоку відмов.

\section{References}

[1] Polyakov, S., Klymenko, A., Nyrkova, L., Malkova, O. (2008) Elektroximichnyj monitoryng magistralnyx truboprovodiv na korozijno- nebezpechnyx dilyankax [Electrochemical monitoring of main pipelines on corrosionhazardous areas]. Fizyko-ximichna mexanika materialiv, no. 7, V. 2. pp. 761-766.

[2] Zhdek, A.Ya., Grudz, V.Ya. (2012) Vyznachennya zalyshkovogo resursu tryvalo ekspluatovanyx naftoprovodiv iz vraxuvannyam nayavnyx korozijnyx defektiv ta umov ekspluataciyi [Determination of residual life of long-term operated oil pipelines taking into account existing corrosion defects and operating conditions]. Naukovyj visnyk: IFNTUNG. no 2(32) pp. 58-66.

[3] Poberezhnyj, L.Ya., Yavorskyj, A. V., Cyx, V. S., Staneczkyj, A. I., Gryczanchuk, A. V. (2017) Pidvyshhennya rivnya ekologichnoyi bezpeky truboprovidnyx merezh naftogazovogo kompleksu Ukrayiny [Improving the level of environmental safety of pipeline networks of the oil and gas complex of Ukraine]. Naukovo-texnichnyj zhurnal «Texnogenno-ekologichna bezpeka». no. 1. pp. 24-31.

[4] Tolkovyj slovar po metrologyy, yzmerytelnoj texnyke yupravlenyyu kachestvom: Osnovnye termyny. M. 1990. pp. 317.

[5] Andrejcev, V.I. (1999). Ekologichnyj ryzyk v systemi pravovidnosyn ekologichnoyi bezpeky: problemy praktychnoyi teoriyi [Ecological risk in the system of legal relations of ecological safety: problems of practical theory]. Pravo Ukrayiny. no. 1. pp. 62-69.

[6] Yarchak, V. (2009). Pro ekologichnyj ryzyk dzherel pidvyshhenoyi ekologichnoyi nebezpeky [About ecological risk of sources of the increased ecological danger]. Visnyk Lviv. un-tu Seriya yuryd. Vyp. 48. pp. 209-215 URL: http://nv.nung.edu.ua/sites/nv.nung.edu.ua/files/journals/032/12zaydue.pdf.

[7] Semchuk, Ya.M., Kry`venko, G.M., Goral`, L.T., Govdyak R.M. (2001) Texnichny`j ta ekologichny`j ry`zy`ky` pry` ekspluataciyi magistral'ny`x truboprovodiv [Technical and environmental risks in the operation of main pipelines]. Rozvidka ta rozrobka naftovyx i gazovyx rodovysh. no. 1. pp. 68-70.

[8] Stryzhevskyj, Y. V., Zynevy`ch, A. M., Ny`kol`sky`j, K. K. (1981) Zashyta metallycheskyx sooruzhenyj ot podzemnoj korrozyy [Protection of metal structures from underground corrosion]: Spravochnyk. 2-e yzd., pererab. Y dop. M. Nedra. 293 p.

[9] Ivanyuta, S.P., Kachynskyj, A.B. (2012) Ekologichna ta pryrodno-texnogenna bezpeka Ukrayiny: regionalnyj vymir zagroz i ryzykiv [Ecological and natural-technogenic security of Ukraine: regional dimension of threats and risks]: monografiya. K.: NISD. 308 p.

[10] Gorbulin, V.P., Kachynskyj, A.B (2007) Systemno-konceptualni zasady strategiyi nacionalnoyi bezpeky Ukrayiny [System-conceptual principles of the national security strategy of Ukraine]. K.: DP «Yevroatlanty`kinform». 592 p.

[11] Kachynskyj, A.B. (2004) Bezpeka, zagrozy i ryzyk: naukovi koncepciyi ta matematychni metody [Security, threats and risk: scientific concepts and mathematical methods]. K.: IPNB. NASBU. 472 p.

[12] Kachynskyj, A.B. (2001) Ekologichna bezpeka Ukrayiny: systemnyj analiz perspektyv pokrashhennya [Environmental security of Ukraine: a systematic analysis of prospects for improvement]. K.: NISD. 312 p.

[13] Golynkevych, T.A. (1977) Prykladnaya teoryya nadezhnosty [Applied reliability theory]. M.: Vyssh. shkola. 160 p.

[14] Kalynyn, V.M. (2006) Ocenka bezotkaznosty y prognozyrovanye dolgovechnosty truboprovodov podzemnoj prokladky [Fault assessment and prediction of the durability of underground pipelines]. Vodoochystka. no. 11. pp. 61-66. URL: http://twt.mpei.ac.ru/OCHKOV/Vodoochistka/Ochkov_11.pdf.

[15] Metodyka vybora nomenklatury normyruemyx pokazatelej nadezhnosty texnycheskyx ustrojstv [Method of selection of the nomenclature of the normalized indicators of reliability of technical devices]: MU 3-69. M.: Yzd-vo standartov, 1970. $39 \mathrm{p}$.

[16] Novoxatnij, V.G., Matyash, O.V. (2015) Remontoprydatnist metalevyx vodoprovidnyx trub [Maintainability of metal water pipes]. Naukovyj visnyk budivnycztva: Zb. nauk. pr. Vyp. no. 2 (80). Xarkiv: XNUBA. XOTV ABU. pp. 254-257. 
Постановка проблеми. Перші збудовані нафтопроводи працюють більше ніж 48 років [1;2], середній термін експлуатації яких становить понад 35 років. Термін експлуатації мережі нафтопроводів України в багатьох випадках вичерпав свій експлуатаційний ресурс. Значні та численні корозійні пошкодження поверхонь труб загострюють проблему надійної та екологічно безпечної експлуатації. Зі збільшенням термінів їх експлуатації все актуальнішою стає проблема оцінювання рівня безпечної експлуатації магістральних нафтопроводів.

Серед основних екологічних проблем, пов'язаних iз функціонуванням нафтогазової галузі, автори [3] виділяють нафтогазотранспорт і вирішення питання техногенної безпеки під час експлуатаційних робіт. Аспектом екологічної безпеки є екологічний ризик, мінімізація якого або запобігання якому підвищує ресурс екологічної безпеки. Загальна категорія ризику розглядається як імовірність настання небажаних подій і наслідків [4]. Екологічний ризик є важливою ознакою екологічної небезпеки, оскільки відображає iii об’єктивну сутність - імовірність настання цього явища [5].

Функціональною особливістю екологічного ризику $є$ його здатність до прояву своїх властивостей протягом усього періоду існування конструкцій, від виникнення через розвиток, зміну до припинення. Ризик передбачає ймовірність настання небажаної події внаслідок впливу зовнішніх або внутрішніх чинників [6].

Дослідження показників, що оцінюють ступінь техногенно-екологічного ризику експлуатації сталевих нафтопроводів, $є$ необхідною передумовою забезпечення безпеки держави, у тому числі й екологічної, шляхом запобігання впливу магістральних нафтопроводів на довкілля в разі їх розгерметизації.

Аналіз останніх досліджень і публікацій. Питанням безпечної експлуатації нафтопроводів i їх екологічної безпеки присвячено праці багатьох учених. Експерти-дослідники: П.П. Бородавкін, Р.М. Говдяк, В.Я. Грудз, Б.І. Кім, Ю.О. Кузьменко, А.Г. Телегін, Я.М. Семчук, Л.С. Шлапак - виділяють низку причин відмов трубопроводів, що створюють техногенно-екологічний ризик.

Виокремлення не вирішених раніше частин загальної проблеми. Незважаючи на важливість надійної та безаварійної експлуатації магістральних нафтопроводів, проблемі оцінювання техногенноекологічних ризиків приділена недостатня увага [7].

Основний ризик аварій і надзвичайних ситуацій на магістральних нафтопроводах пов'язаний з аваріями на лінійних ділянках [8]. Найбільший ризик аварій виникає на ділянках, що мають тріщини, підводні переходи, перетини з іншими трубопроводами, автомобільними й залізничними дорогами, лініями електропередач тощо.

Як зазначено [9-11], рівень екологічної безпеки визначається величиною ризику від можливих техногенних катастроф. Аналіз ризиків пов'язаний з аналі- зом загроз, що визначають рівень безпеки. Основою оцінювання ризиків є теорія надійності, відповідно до якої аварійні ситуації доцільно розглядати як відмови елементів системи, що призводять до порушення їх стійкості [12].

Доцільно розглядати у взаємозв'язку техногенно-екологічні ризики експлуатації нафтопроводів 3 прогнозуванням екологічних наслідків у разі виникнення аварійної ситуації. Тому проблема оцінювання техногенно-екологічного ризику під час експлуатації нафтопроводів, безумовно, є актуальною й своєчасною. У процесі проектування та експлуатації нафтопроводів недостатньо враховується їх вплив на навколишнє середовище й оцінюється ступінь екологічної безпеки під час їх експлуатації. Аналіз причин відмов нафтопроводів показує, що більше ніж 60\% усіх відмов сталися з причин корозійного руйнування труб.

Мета дослідження. Виконати розрахунки ймовірностей виникнення надзвичайних ситуацій унаслідок розгерметизації сталевих нафтопроводів 3 урахуванням корозійних процесів.

Методи, об'єкт та предмет дослідження. Об’єкт дослідження - оцінювання ризиків забруднення довкілля внаслідок розгерметизації сталевих нафтопроводів як потенційних джерел забруднення довкілля внаслідок витоку нафтопродуктів, продуктів їх згоряння або вибуху.

Для вирішення поставлених завдань у роботі використовувалися сучасні методи наукових досліджень: аналіз - для узагальнення сучасних науковотехнічних досягнень; математичне моделювання.

Основний матеріал (результати). Україна має розгалужену мережу сталевих нафтопроводів сумарною протяжністю майже 5000 км, які є об'єктами підвищеної небезпеки з погляду сучасних екологічних вимог. У разі їх розгерметизації виникають екологічні ризики забруднення довкілля внаслідок витоку нафтопродуктів, можливих пожеж, вибухів тощо. Наприклад, значна екологічна катастрофа, пов'язана з витоком нафтопродуктів через розгерметизацію нафтопроводу, трапилася в 1994 р. в Республіці Комі, Росія. У результаті появи на трубопроводі корозійних пошкоджень стався масовий витік нафти. При цьому втрата нафтопродуктів становила до 580 тис. барелів. Площа забрудненої грунтової поверхні - до 115 га. Одним із негативних чинників, які підвищують екологічні ризики виникнення надзвичайних ситуацій, пов'язаних із забрудненням грунтів, водойм, атмосферного повітря, є зовнішні та внутрішні корозійні процеси сталевих нафтопроводів.

Екологічна безпека нафтопроводів визначається величиною ймовірності випадків забруднення довкілля внаслідок розгерметизації сталевих нафтопроводів, у тому числі з урахуванням зовнішніх i внутрішніх корозійних процесів. Загалом екологічний ризик розглядається як імовірність настання небажаних подій і наслідків, є важливою ознакою екологічної безпеки. Імовірність відмови нафтопроводу 
протягом року $Q(t)$ доцільно вважати ймовірністю виникнення екологічного ризику.

Для розрахунку ймовірності випадків забруднення довкілля внаслідок розгерметизації сталевих нафтопроводів запропоновано теорію надійності, відповідно до якої аварійні витоки нафти розглядають як еколого-техногенний ризик, що призводить до порушення стійкості компонентів навколишнього середовища. Згідно із зазначеною теорією, показником надійності відновлюваних об'єктів, до яких зараховують і нафтопроводи, є безвідмовність. Безвідмовність оцінюється ймовірністю безаварійної роботи, параметром потоку аварійних подій і проміжком часу безаварійної роботи.

Виділяють такі показники безвідмовності [13-14]:

- імовірність безвідмовної роботи - це ймовірність того, що протягом заданого відрізку часу відмова нафтопроводу або його ділянки не відбудеться;

- $\quad$ параметр потоку відмов - це відношення математичного сподівання кількості відмов нафтопроводу або його ділянки до напрацювання за досить малий відрізок часу;

- $\quad$ напрацювання на відмову - це випадковий час роботи нафтопроводу або його ділянки від відновлення після ремонту до наступної відмови.

Важливим завданням $є$ вибір основних показників надійності з указаного переліку показників. У теорії надійності розроблена методика вибору основних показників надійності $[15 ; 16]$. Основою такого вибору є домінуючі фактори та наслідки, які виникають у разі відмови.
Кількісною мірою виникнення відмов для систем трубопровідного транспорту доцільно взяти ймовірність виникнення відмови $Q(t)$ протягом часу роботи $t$. Протилежна їй імовірність $P(t)=1-Q(t)$ - це ймовірність безвідмовної роботи нафтопроводів:

$$
P(t)=P\left\{t \geq t_{i}\right\}
$$

де $t_{i}$ - довільний відрізок часу.

Для розрахунку середнього значення питомого параметра потоку відмов $\omega 0 \mathrm{mid}$ використана формула:

$$
\omega_{0 \text { mid }}=\frac{n}{t \times \sum L}, 1 / \text { рік·км або 1/год·км, }
$$

де $\mathrm{n}$ - кількість відмов ділянок нафтопроводів; $t$ термін спостереження (роки або години); $\sum \mathrm{L}-$ протяжність нафтопроводів, км; $\omega_{0 \mathrm{i}}-$ питомий параметр потоку відмов ділянки нафтопроводу $i$-го діаметра та матеріалу труб, 1/рік`км.

Параметр потоку відмов ділянки нафтопроводу розраховується за формулою:

$$
\omega_{H n}=\omega_{0} \times L .
$$

Напрацювання на відмову нафтопроводу:

$$
T=\frac{1}{\omega_{\text {ни }}}, \text { год. }
$$

Імовірність безвідмовної роботи визначається за

\begin{tabular}{|c|c|c|c|c|}
\hline Назва нафтопроводів & $\begin{array}{c}\text { Параметр } \\
\text { потоку } \\
\text { аварійних } \\
\text { подій, } \grave{\boldsymbol{u}} 1 / \text { рік }\end{array}$ & $\begin{array}{c}\text { Проміжок часу } \\
\text { безаварійної } \\
\text { роботи, } \boldsymbol{T}, \text { рік }\end{array}$ & $\begin{array}{c}\text { Імовірність } \\
\text { безаварійної } \\
\text { роботи протягом } \\
\text { року, } \mathrm{P}(\mathrm{t}) \\
\end{array}$ & $\begin{array}{c}\text { Імовірність виникнення } \\
\text { аварії протягом року, } \\
\mathrm{Q}(\mathrm{t})\end{array}$ \\
\hline 1 & 2 & 3 & 4 & 5 \\
\hline Мічурінськ-Кременчук & 0,086975 & 11,5 & 0,91670 & 0,08330 \\
\hline $\begin{array}{l}\text { Гнідинці- Глинсько-Розбишівська I, } \\
\text { II нитки }\end{array}$ & 0,031507 & 31,7 & 0,96898 & 0,03102 \\
\hline Глинсько-Розбишівська-Кременчук & 0,036333 & 27,5 & 0,96432 & 0,03568 \\
\hline М Павлівка-Глинсько-Розбишівська & 0,018056 & 55,4 & 0,98211 & 0,01789 \\
\hline Самара-Лисичанськ & 0,040351 & 24,8 & 0,96045 & 0,03955 \\
\hline Лисичанськ-Тихорецьк I, II нитки & 0,101381 & 9,9 & 0,90359 & 0,09641 \\
\hline $\begin{array}{l}\text { «НПС Лисичанськ»-Писичанський } \\
\text { НПЗ І, ІІ нитки }\end{array}$ & 0,003430 & 291,5 & 0,99658 & 0,00342 \\
\hline Лисичанськ-Кременчук & 0,103218 & 9,7 & 0,90193 & 0,09807 \\
\hline Кременчук-Херсон & 0,096432 & 10,4 & 0,90807 & 0,09193 \\
\hline Снігурівка-Одеса & 0,061176 & 16,3 & 0,94066 & 0,05934 \\
\hline Мозир-Броди I, II черга & 0,178188 & 5,6 & 0,83678 & 0,16322 \\
\hline Броди-Держкородон I, II черга & 0,159250 & 6,3 & 0,85278 & 0,14722 \\
\hline Відвід на Угорщину & 0,005365 & 186,4 & 0,99465 & 0,00535 \\
\hline Одеса-Броди & 0,165056 & 6,1 & 0,84785 & 0,15215 \\
\hline Долина-Дрогобич & 0,014381 & 69,5 & 0,98572 & 0,01428 \\
\hline Жулин-Дрогобич & 0,010559 & 94,7 & 0,98950 & 0,01050 \\
\hline Орів-Дрогобич & 0,005831 & 171,5 & 0,99419 & 0,00581 \\
\hline Борислав-Дрогобич & 0,001984 & 504,0 & 0,99802 & 0,00198 \\
\hline Всього & 1,167915 & 0,856 & 0,31101 & 0,68899 \\
\hline
\end{tabular}
формулою:

Таблиця 1. Результати розрахунку ймовірностей виникнення надзвичайних ситуацій, пов'язаних із витоком, згорянням або вибухами нафтопродуктів унаслідок розгерметизації нафтопроводів і шкідливим впливом на довкілля 


$$
P(t)=e^{-\omega t}
$$

Результати розрахунків надійності нафтотранспортної системи наведено в таблиці 1.

Середній термін служіння нафтопроводів можна визначити як математичне сподівання напрацювання до відмови для невідновлюваного об'єкта незалежно від виду розподілу.

За результатими розрахунків виявлено, що найбільш небезпечними за показником потоку відмов $є$ нафтопроводи: Мозир-Броди I, II черга; Броди-Держкородон I, II черга; відвід на Угорщину км 0-21,4; Одеса-Броди.

Обговорення отриманих результатів. Оцінювання ступеня техногенно-екологічного ризику експлуатації нафтопроводів України дає можливість визначити найбільш небезпечні ділянки нафтопроводів, що дасть змогу своєчасно планувати відповідні ремонтні роботи, запобігти створенню аварійних ситуацій та отримати соціальний, економічний та екологічний ефекти від зменшення навантаження на компоненти навколишнього середовища.

Оцінювання техногенно-екологічного ризику експлуатації магістральних нафтопроводів дає можливість раціонально спланувати ремонтні роботи, прогнозувати реальні строки роботи конструкції, тим самим забезпечивши екологічно безпечне їх функціонування.

Висновки. Отже, у роботі розраховано ймовірність виникнення екологічної загрози внаслідок прояву корозійних процесів на сталевих нафтопроводах і визначено ii значення, яке становить одну аварію за 10 місяців. Результати наукової роботи в комплексі $з$ іншими дослідженнями дадуть змогу визначити потенційні екологічні загрози від корозії трубопроводів, що дасть можливість розробити заходи із запобігання виникненню шкідливих впливів у разі розгерметизації нафтопроводів.

\section{Список літератури:}

[1] Електрохімічний моніторинг магістральних трубопроводів на корозійно-небезпечних ділянках / С. Поляков, А. Клименко, Л. Ниркова, О. Малькова. Фізико-хімічна механіка матеріалів. 2008. № 7. Т. 2. С. 761-766.

[2] Ждек А.Я., Грудз В.Я. Визначення залишкового ресурсу тривало експлуатованих нафтопроводів із врахуванням наявних корозійних дефектів та умов експлуатації. Науковий вісник: ІФНТУНГ. 2012. № 2 (32). C. $58-66$.

[3] Підвищення рівня екологічної безпеки трубопровідних мереж нафтогазового комплексу України / Л.Я. Побережний, А.В. Яворський, В.С. Цих, А.І. Станецький, А.В. Грицанчук. Науково-технічний журнал «Техногенно-екологічна безпека». 2017. № 1. С. 24-31.

[4] Толковый словарь по метрологии, измерительной технике и управлению качеством: Основные термины. Москва, 1990. С. 317.

[5] Андрейцев В.І. Екологічний ризик в системі правовідносин екологічної безпеки:проблеми практичної теорії. Право України. 1999. № 1. С. 62-69.

[6] Ярчак В. (2009). Про екологічний ризик джерел підвищеної екологічної небезпеки. Вісник Львівського університету. Серія «Юридична». 2009. Вип. 48. С. 209-215. URL: http://nv.nung.edu.ua/sites/nv.nung.edu.ua/ files/journals/032/12zaydue.pdf.

[7] Технічний та екологічний ризики при експлуатації магістральних трубопроводів / Я.М. Семчук, Г.М. Кривенко, Л.Т. Гораль, Р.М. Говдяк. Розвідка та розробка нафтових $і$ газових родовищ. 2001 . № 1. C. $68-70$.

[8] Стрижевский И.В., Зиневич А.М., Никольский К.К. Защита металлических сооружений от подземной коррозии : справочник. 2-е изд., перераб. и доп. Москва : Недра, 1981. 293 с.

[9] Іванюта С.П., Качинський А.Б. Екологічна та природно-техногенна безпека України: регіональний вимір загроз і ризиків : монографія. Київ : НІСД, 2012. 308 с

[10] Горбулін В.П., Качинський А.Б. Системно-концептуальні засади стратегії національної безпеки України. Київ : ДП «Свроатлантикінформ», 2007. 592 с.

[11] Качинський А.Б. Безпека, загрози і ризик: наукові концепції та математичні методи. Київ : ІПНБ. НАСБУ, 2004. 472 c.

[12] Качинський А.Б. Екологічна безпека України: системний аналіз перспектив покращення. Київ : НІСД, 2001. 312 c.

[13] Голинкевич Т.А. Прикладная теория надежности. Москва : Высш. школа, 1977. 160 с.

[14] Калинин В.М. Оценка безотказности и прогнозирование долговечности трубопроводов подземной прокладки. Водоочистка. 2006. № 11. C. 61-66. URL: http://twt.mpei.ac.ru/OCHKOV/Vodoochistka/Ochkov_11.pdf.

[15] Методика выбора номенклатуры нормируемых показателей надежности технических устройств: МУ 3-69. Москва : Изд-во стандартов, 1970. 39 с.

[16] Новохатній В.Г., Матяш О.В. Ремонтопридатність металевих водопровідних труб. Науковий вісник будівництва : збірник наукових праць. Харків : ХНУБА. ХОТВ АБУ, 2015. Вип. № 2 (80). С. $254-257$. 